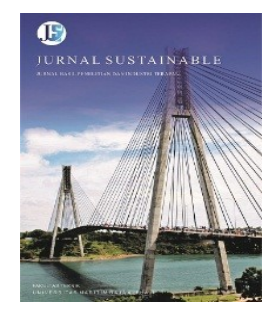

\title{
Analisis Performansi Jaringan 4G Operator Telkomsel di Kota Tanjungpinang Menggunakan Metode Drive Test
}

\author{
Fitri Farida ${ }^{1, *}$, Anton Hekso Yunianto ${ }^{2}$ \\ ${ }^{1,2}$ Jurusan Teknik Elektro, Fakultas Teknik, Universitas Maritim Raja Ali Haji \\ ${ }^{1,2}$ Jl. Politeknik Senggarang, Tanjungpinang 29100 \\ *Corresponding Author: fitri.farida.fte@umrah.ac.id
}

\begin{abstract}
The existence of a 4G network in Tanjungpinang City has begun to be felt by the community. The number of $4 \mathrm{G}$ service users continues to increase, so optimal observation is needed on the quality of the $4 \mathrm{G}$ network. Analysis of $4 \mathrm{G}$ network performance can be obtained using the drive test method. This method is used to obtain network quality information in real terms in the field. In line with advances in drive test technology, it can be applied more easily, namely using GNetTrack Pro software. The parameters measured to determine the quality of $4 \mathrm{G}$ networks in this study are SINR (Signal to Interference Noice Ratio), RSRP (Reference Signal Receives Power), RSRQ (Reference Signal Receives Quality). Location of the measurement in Tanjungpinang City with the drive test route is started from Ali Haji street- Basuki Rahmat street - Wiratno street Sekarno Hatta street - Yos Sudarso street - Usman Harun street - POS street - Bakar Batu street Brigjen Katamso street - MT Haryono street. The result shows 4G Telkomsel has a good quality with value RSRP -83.48 dBm, RSRQ -11.18 dB, SINR 6.71 dB.
\end{abstract}

Keywords-drive test, $4 G$, RSRP, RSRQ, SINR.

Intisari-Keberadaan jaringan $4 \mathrm{G}$ di Kota Tanjungpinang mulai dirasakan manfaatnya oleh masyarakat. Jumlah pengguna layanan $4 \mathrm{G}$ yang terus meningkat, sehingga dibutuhkan pengamatan yang optimal terhadap kualitas jaringan 4G. Analisis performansi jaringan $4 \mathrm{G}$ dapat diperoleh dengan metode drive test. Metode ini digunakan untuk mendapatkan informasi kualitas jaringan secara real di lapangan. Sejalan kemajuan teknologi drive test dapat diterapkan dengan lebih mudah yaitu menggunakan software G-NetTrack Pro. Parameter yang diukur untuk menentukan kualitas jaringan 4G pada penelitian ini adalah SINR (Signal to Interference Noice Ratio), RSRP (Reference Signal Receives Power), RSRQ (Reference Signal Receives Quality). Lokasi pengukuran di Kota Tanjungpinang dengan rute drive test yaitu dimulai dari Jl. Ali Haji - Jl. Basuki Rahmat - Jl. Wiratno - Jl. Sekarno Hatta - Jl. Yos Sudarso - Jl. Usman Harun - Jl. POS - Jl. Bakar Batu - Jl. Brigjen Katamso - Jl. MT Haryono. Hasil pengukuran jaringan 4G Telkomsel menunjukkan nilai RSRP -83,48 dBm, RSRQ -11,18 dB, SINR 6,71 dB.

Kata kunci-drive test, 4G, RSRP, RSRQ, SINR.

\section{Pendahuluan}

Perkembangan teknologi telekomunikasi di dunia terjadi sangat pesat karena adanya kebutuhan untuk berkomunikasi dan bertukar data dengan cepat dan mudah dengan mobile phone. Perkembangan komunikasi ditandai dengan pengembangan teknologi sistem komunikasi bergerak yang dimulai dari generasi pertama ke generasi berikutnya, yaitu teknologi terbaru jaringan $4 \mathrm{G}$ atau LTE. LTE merupakan pengembangan dari teknologi sebelumnya yakni UMTS $(3 \mathrm{G})$ dan HSPA $(3,5 \mathrm{G})$. 
Pada tahun 2016 Telkomsel resmi luncurkan jaringan 4G LTE di Kota Tanjungpinang (Batam Tribun News). Sebagai ibukota provinsi Kepri, Tanjungpinang menjadi bagian tidak terpisahkan dari upaya mendukung perkembangan dan kemajuan Kepri. Dengan beroperasinya layanan Telkomsel 4G LTE di Tanjungpinang diharapkan akan memberikan pengalaman terbaik bagi pelanggan dalam menikmati layanan mobile broadband yang cepat dan stabil.

Keberadaan jaringan 4G LTE di Tanjungpinang mulai dirasakan manfaatnya oleh masyarakat Tanjungpinang. Dengan jumlah pengguna layanan $4 \mathrm{G}$ yang terus meningkat, maka dibutuhkan pengamatan yang optimal terhadap kualitas jaringan 4G LTE. Penelitian ini membahas mengenai kualitas sinyal dan coverage area (daerah cakupan) jaringan $4 \mathrm{G}$ LTE operator Telkomsel di Kota Tanjungpinang. Kinerja coverage dilihat dari parameter RSRP, sedangkan kinerja kualitas sinyal dilihat dari parameter SINR. Kinerja diukur dari jumlah persentase area yang mendapatkan nilai parameter yang optimal.

Perencanaan optimalisasi pada suatu jaringan LTE, para provider melakukan drive test pada daerah converage area menggunakan aplikasi G-NetTrack Pro. Pada penelitian ini dibuat data hasil drive test secara pergerakan sehingga data dapat diakses pada handphone langsung. Proses umum dari sistem ini adalah proses analisa port dari handphone dan GPS, yang kemudian data diambil dari handphone yang berisi data level daya dan parameter lainnya atau data dari GPS yang merupakan data posisi. Sistem ini dihasilkan dari penelitian berupa sistem pengiriman data hasil drive test secara wireless untuk perencanaan dan optimalisasi jaringan $4 \mathrm{G}$.

\section{Penelitian Literatur}

\section{A. Kajian Terdahulu}

Kajian terdahulu terkait penelitian ini dilakukan oleh [1], dengan judul penelitian analisis performansi dan optimalisasi coverage layanan LTE Telkomsel di Denpasar Bali. Penelitian tersebut menggunakan metode drive test dengan software Nemo Outdoor untuk menentukan performansi kualitas jaringan LTE dan diperoleh nilai parameter LTE Telkomsel 42,12\% untuk RSRP Idle Mode 41,12 \% untuk RSRP Dedicated Mode, 98,61\% untuk SINR, 82,3 \% untuk Download Throughput, dan 59,78 $\%$ untuk Upload Throughput.

Kemudian Penelitian yang dilakukan oleh [2] dengan judul penelitian Analisis perbandingan kuat sinyal 4G LTE antara operator Telkomsel dan XL AXIATA berdasarkan parameter Drive Test menggunakan software G-NetTrack Pro di Area Jalan Protokol Panam. Pada penelitian tersebut diperoleh hasil bahwa daerah Panam operator XL-AXIATA kualitas kuat sinyal lebih baik dari operator Telkomsel yaitu -56, dan nilai kuat sinyal terbaik untuk operator Telkomsel nilai -62, dan untuk jalan protokol Panam kuat sinyal 4G LTE terbaik yaitu dijalan SM. Sedangkan kuat sinyal terburuk dijalan Air Hitam. Jumlah Enode-B untuk operator Telkomsel ada 24 Enode-B, sedangkan untuk operator XL-AXIATA 32 Enode-B yang melayani saat proses Drive Test dilakukan.

Penelitian [3] yang berjudul Analisis Quality of Service (QOS) jaringan 4G dengan metode drive test pada kondisi outdoor menggunakan aplikasi G-NetTrack Pro. Hasil pengukuran kekuatan dan kualitas sinyal kemudian dicari letak eNodeB terbaik untuk dilakukan pengukuran kecepatan download, kecepatan upload, latency dan jitter menggunakan software nPerf Speedtest. Hasil analisis menunjukkan bahwa terdeteksi 9 eNodeB dan 17 Cell dengan rata-rata RSRP sebesar -78,2 dBm pada lokasi Kampus, sedangkan pada lokasi Tembalang terdeteksi 15 eNodeB dan 32 Cell dengan rata-rata RSRP sebesar -77,27 dBm. Rata-rata pengukuran RSRP masih jauh dari hasil perhitungan yang diharapkan. Rata-rata latency pengukuran sebesar 48,04 ms, sedangkan rata-rata pengukuran jitter sebesar 46,64 ms. Rata-rata pengukuran kecepatan download adalah 39,22 Mbps, sementara rata-rata pengukuran kecepatan upload sebesar 29,89 Mbps. 
Tahap peningkatan performasi jaringan $4 \mathrm{G}$ LTE [4] dengan melakukan penambahan eNodeB baru (new site) berdasarkan bad spot area, hal ini karena dilokasi penelitian didominasi oleh RSRP (kuat sinyal) kategori lemah atau poor (-110 dBm sampai $-100 \mathrm{dBm})$. Penelitian yang dilakukan [5] melihat dari segi kinerja kualitas sinyal (SINR) dan juga melihat parameter throughput (downlink maupun uplink) untuk melihat pengaruh yang diberikan SINR.

\section{B. Kajian Teori}

1) Pengenalan 4G LTE : Long Term Evolution (LTE) LTE diperkenalkan untuk memenuhi peningkatan permintaan untuk kecepatan akses yang lebih tinggi untuk aplikasi multimedia. Teknologi ini merupakan teknologi pra-4G yang didefinisikan dalam standar 3GPP Release 8. Menurut standar, LTE memberikan kecepatan downlink hingga $100 \mathrm{Mbps}$ dan 50 Mbps untuk uplink pada channel bandwidth 20 MHz. Berdasarkan keunggulannya LTE didukung teknologi OFDMA (Orthogonal Frequency Division Multiple Access) untuk arah downlink, kemudian teknologi SC-FDMA (Single Carrier Frequency Division Multiple Access) untuk arah uplink untuk mencapai data rates yang lebih tinggi dan penggunaan bandwidth yang maksimal dan efisien. Perkembangan teknologi telekomunikasi seluler telah berkembang dari Generasi Pertama (1G) hingga Generasi Ketiga (3G), bahkan sekarang sudah dikembangkan menjadi Generasi Keempat (4G).

2) Pengenalan G-NetTrack Pro: G-Net Track adalah aplikasi untuk memonitor jaringan dan walk test pada perangkat yang beroperasi sistem OS Android. Teknologi yang didukung pada aplikasi G-Net Track Pro adalahLTE,UMTS, GSM, CDMA, EVDO, HSDPA. Pe-ngukuran juga bisa dilakukan pada lokasi indoor dan outdoor. Informasi yang bisa didapatkan de-ngan menggunakan software Gnettrack adalah Rxlev, Rxqual, SQI, MCC, MNC,CI, LAC, Time, Langitude, Latitude, Upload, Download, Type jaringan yang digunakan atau operator yang digunakan. a) Cell : Berisi ringkasan data sektor BTS yang sekarang melayani HP kita mulai dari MCC, MNC, LAC, RNC, CELLID. Dibawah ini adalah tampian gambar dari Cell.

b) Nei: Berisi informasi cell neighbors/tetangga di sekitar cell yang sekarang melayani kita. Tetapi, seperti disebutkan oleh developer-ya, cell neighbors ini hanya bisa ditampilkan dibeberapa jenis HP yang telah dites sebelumnya.

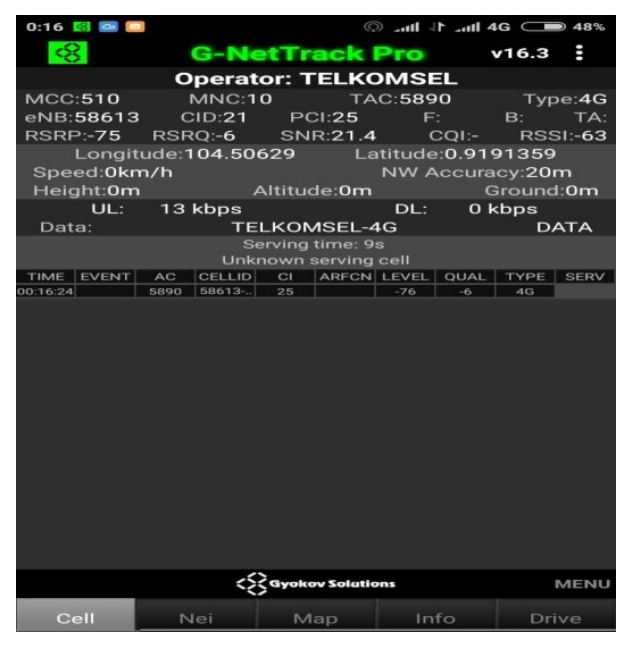

Gambar 1. Tampilan Cell

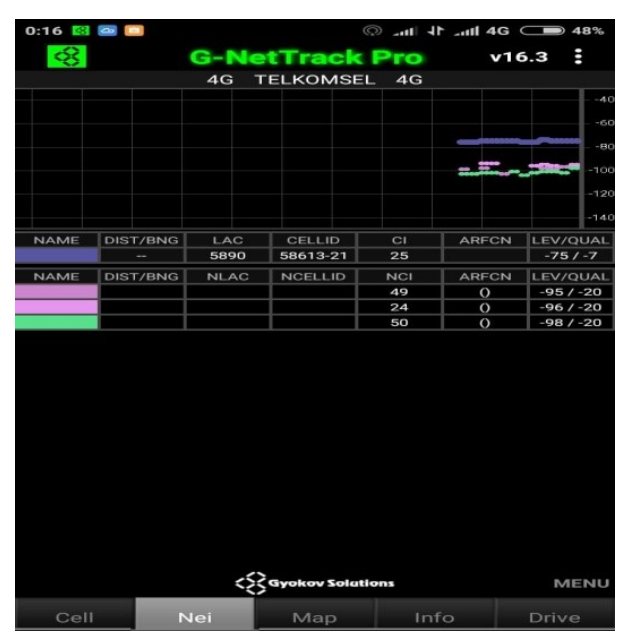

Gambar 2. Tampilan $N e i$

c) Map: Berisi peta google map. Ada pilihan untuk memilih informasi apa yang akan ditampilkan di peta ini, yakni level kuat sinyal yang diterima, Kualitas, Cell, Download rate, Upload rate dan kecepatan. Yang sedikit mengganggu adalah tingkat pewarnaan yang tidak lazim saat kita memilih level. Umumnya, saat drive test, sinyal terkuat sampai terlemah 
akan digambar dengan titik berwarna hijau terang - kuning - jingga dan merah untuk sinyal terlemah. Namun dalam aplikasi ini, terkuat adalah merah - jingga - kuning - hijau - biru abu-abu dan hitam untuk yang terlemah.

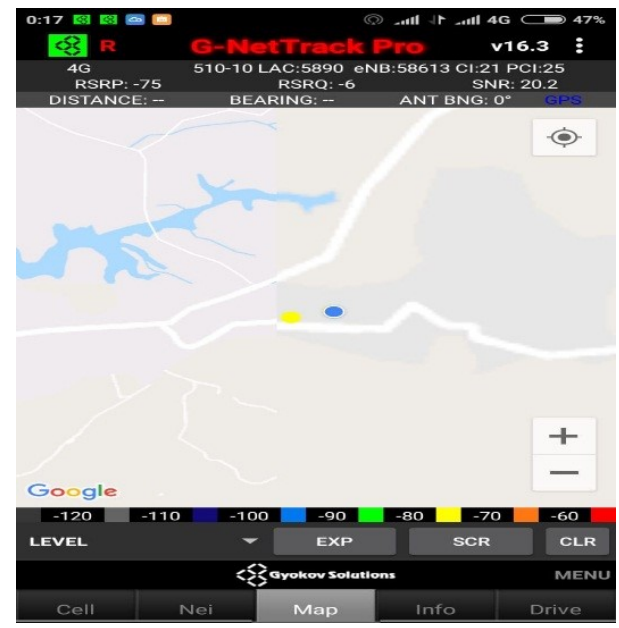

Gambar 3 Tampilan Map

d) Info: Berisi informasi tentang HP dan sofware G-NetTrack yang sedang dipakai.

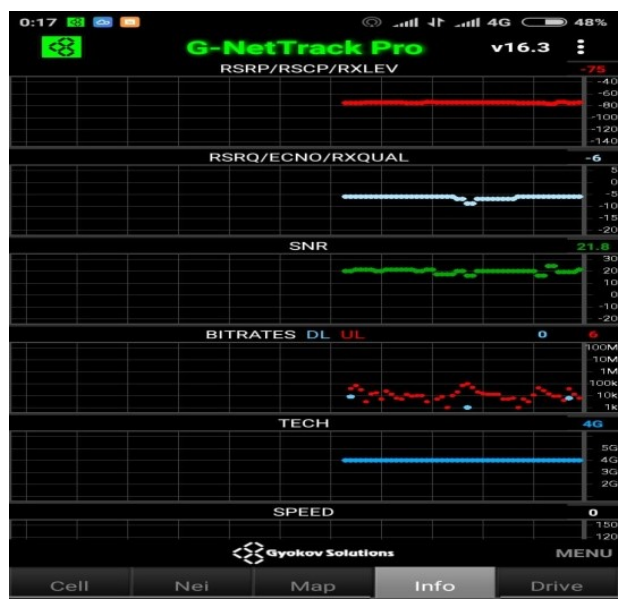

Gambar 4. Tampilan Info

e) Drive: Berisi tentang menu yang mengakumulasi hasil dari keseluruhan menumenu sebelumnya. Seperti prioritas sinya, kualitas, BTS, RSRQ, TAC, ENB, ARFCN, TA, TECH.

3) Drive Test: Merupakan pengukuran kualitas sinyal pemancar / BTS ke MS / handphone atau sebaliknya. Tujuan drive test adalah untuk mengumpulkan informasi jaringan radio frekuensi secara real dilapangan. Beberapa parameter yang digunakan dalam drive test pada teknologi LTE yaitu :

a) RSRP (Reference Signal Received Power): Power dari sinyal reference atau kuat sinyal yang diterima dalam satuan $\mathrm{dBm}$. Parameter ini adalah parameter yang spesifik pada drive test 4G LTE dan digunakan oleh perangkat untuk menentukan titik handover. Pada teknologi $2 \mathrm{G}$ parameter ini bisa dianalogikan seperti RxLev, sedangkan pada teknologi 3G dianalogikan seperti RSCP.

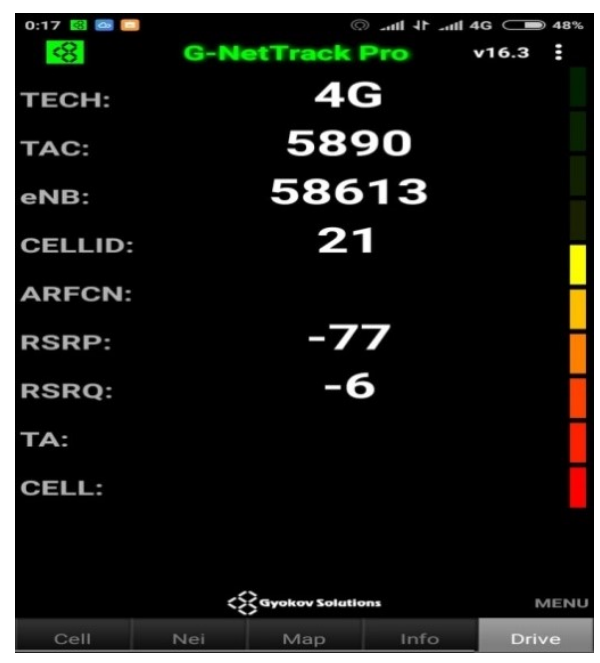

Gambar 5 Tampilan Drive

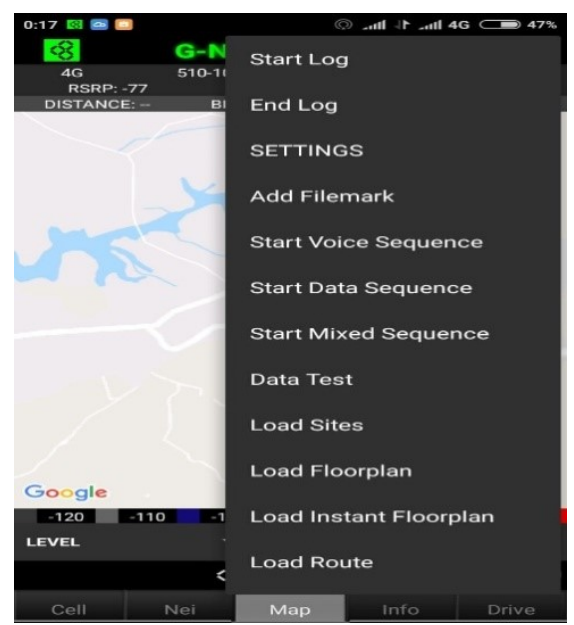

Gambar 6. Tampilan Menu pada

b) RSRQ (Reference Signal Receive Quality): adalah rasio antara RSRP dan wideband power. RSRQ merupakan kualitas sinyal yang diterima UE (User Equipment). 
RSRQ juga dipengaruhi oleh sinyal,dan noise dan juga interference yang diterima EU.

c) SINR (Signal Interference to Noise Ratio): Merupakan perbandingan kuat sinyal dibandingkan noise background.

\section{Metode Penelitian}

Metedo dalam pengukuran kuat sinyal pada penelitian ini adalah dilakukan dengan drive test, menggunakan software G-Net TrackPro

\section{A. Menentukan Operator Jaringan}

Operator telekomunikasi merupakan perusahaan yang menyediakan jaringan telekomunikasi seluler. Pada penelitian ini hanya mengukur kualitas sinyal 4G pada operator Telkomsel karena merupakan penyedia jaringan GSM terbesar dan memiliki jaringan $4 \mathrm{G}$ di Kota Tanjungpinang.

\section{B. Menetukan Rute Drive Test}

Pada penentuan rute drive test dipilih berdasarkan jenis geografis, yaitu Rulal, sub Urban dan Urban. Daerah urban ditandai dengan banyaknya gedung bertingkat dan sebagai pusat pemerintahan dan pelayanan masyarakat.

Parameter daerah urban yang mempengaruhi perambatan gelombang radio adalah kerapatan rumah, tinggi atau daerah kota besar adalah daerah yang memiliki penghalang yang tinggi dari 20 meter [3].

Pada penelitian ini penentuan rute didasarkan pada kepadatan penduduk dan banyaknya aktifitas masyarakatnya, maka ditentukan rute drive test melalui jalan protokol kota Tanjungpinang, yaitu :

- Jl. Ali Haji

- Jl. Basuki Rahmat

- Jl. Wiratno

- Jl. Soekarno Hatta

- J1. Yos Sudarso

- Jl. Usman Harun

- Jl. POS

- Jl. Bakar Batu

- J1. Brigjen Katamso

- J1. MT Haryono

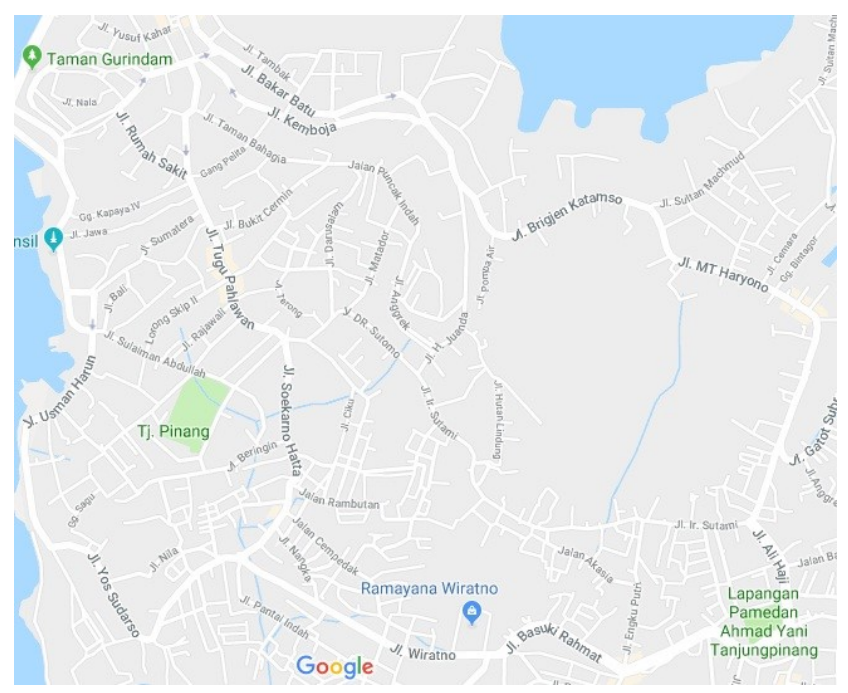

Gambar 7. Jalan Protokol TanjungPinang

\section{Hasil Penelitian}

Pada Bagian dari tahap ini hasil drive test akan menghasilkan beberapa parameter sesuai parameter drive test seperti RSRP, RSRQ, SNIR, dan informasi cell EnodeB yang meng-cover daerah saat melakukan drive test.

\section{A. Survey Rute}

Sebelum melakukan kegiatan drive test dilakukan survey lapangan untuk untuk mendapatkan informasi terkait letak BTS $4 \mathrm{G}$ di Kota Tanjungpinang.

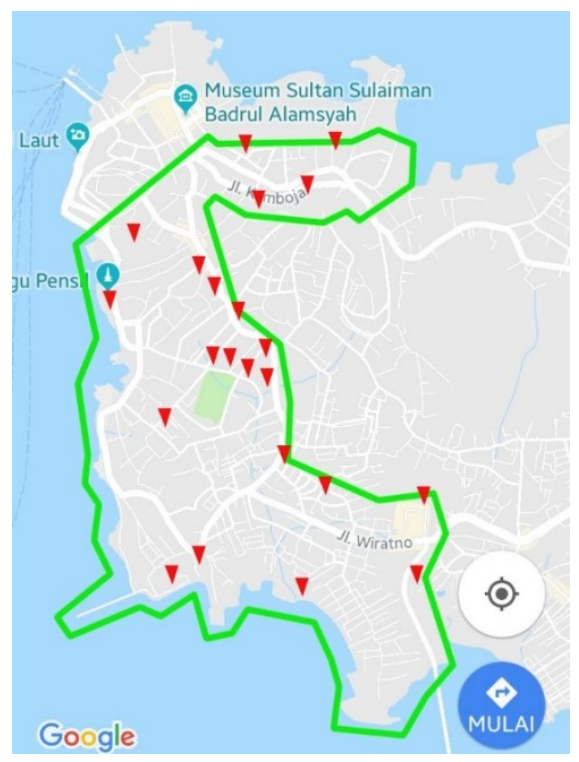

Gambar 8. Lokasi Letak EnodeB 


\section{B. Hasil Pengukuran}

Pengukuran hasil drive dilakukan beberapa kali pengukuran, sehingga mendapatkan nilai rata - rata dari parameter - parameter yang diinginkan.

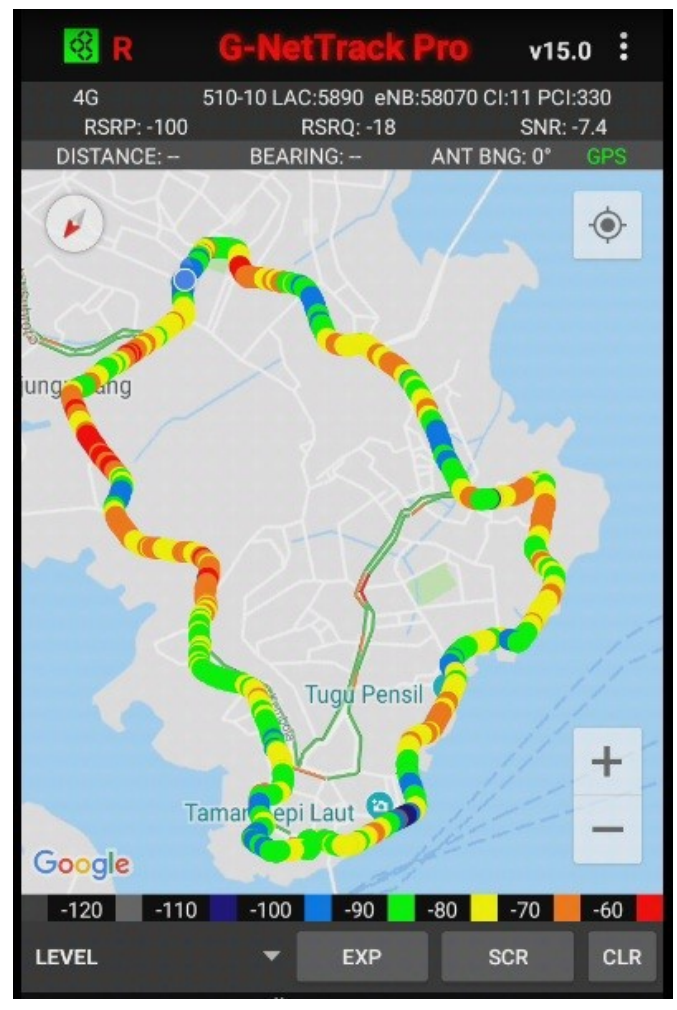

Gambar 9. Hasil dari Drive Test

Tabel 1. Keterangan warna

\begin{tabular}{|c|c|}
\hline Warna & Range Nilai RSRP \\
\hline & $(\leq-60) \times(-40)$ \\
\hline & $(\leq-70) \times(-60)$ \\
\hline & $(\leq-80) \times(-70)$ \\
\hline & $(\leq-90) \times(-80)$ \\
\hline & $(\leq-100) \times(-90)$ \\
\hline & $(\leq-110) \times(-100)$ \\
\hline
\end{tabular}

\section{Analisis Hasil}

Berdasarkan hasil drive test maka diperoleh nilai setiap parameter :

\section{1) Nilai RSRP}

Dari data yang diperoleh nilai RSRP adalah $-83,48 \mathrm{dBm}$. Berdasarkan Standar KPI jaringan Telkomsel 4G maka nilai RSRP termasuk dalam kategori Good

Tabel 2. Standar Nilai RSRP

\begin{tabular}{|c|c|}
\hline Kategori & Range Nilai RSRP \\
\hline Very good & $(-80) \leq \mathrm{x}$ \\
\hline Good & $(\leq-90) \mathrm{x}<(-80)$ \\
\hline Normal & $(\leq-100) \mathrm{x}<(-90)$ \\
\hline Bad & $(\leq-120) \mathrm{x}<(-100)$ \\
\hline Very bad & $(<-120) \mathrm{x}$ \\
\hline
\end{tabular}

\section{2) Nilai $R S R Q$}

Nilai RSRQ adalah $-11,18 \mathrm{~dB}$ tergolong kategori Normal.

Tabel 3. Standar Nilai RSRQ

\begin{tabular}{|c|c|}
\hline Kategori & Range Nilai RSRQ \\
\hline Very good & $(-9) \leq$ \\
\hline Good & $(-10) \leq \mathrm{x}<(-9)$ \\
\hline Normal & $(-15) \leq \mathrm{x}<(-10)$ \\
\hline Bad & $(-19) \leq \mathrm{x}<(-15)$ \\
\hline Very bad & $(-20)<$ \\
\hline
\end{tabular}

\section{3) Nilai SINR}

Nilai SINR yang diperoleh pada tahapan drive test ini adalah SINR 6,71 dB maka dapat digolongkan dalam kategori Good.

Tabel 4. Standar Nilai SINR

\begin{tabular}{|c|c|}
\hline Kategori & Range Nilai RSRQ \\
\hline Very good & $(30) \leq \mathrm{x}<(15)$ \\
\hline Good & $(15) \leq \mathrm{x}<(0)$ \\
\hline Normal & $(0) \leq \mathrm{x}<(-5)$ \\
\hline Bad & $(-5) \leq \mathrm{x}<(-11)$ \\
\hline Very bad & $(-11) \leq \mathrm{x}<(-20)$ \\
\hline
\end{tabular}




\section{KESIMPULAN}

Implementasi kualitas jaringan 4G di Kota Tanjungpinang secara umum adalah baik, namun pada lokasi padat dan banyak gedung tinggi maka kualitas sinyal menurun dan tidak stabil. Pengukuran berdasarkan waktu dan cuaca. Terdapat perbedaan pengaruh penurunan kekuatan sinyal pada cuaca hujan. Secara keseluruhan untuk parameter drive test yang diperoleh nilai RSRP - 83,48 dBm, RSRQ $11,18 \mathrm{~dB}$, SINR 6,71 dB.

\section{REFERENSI}

[1] Afroz, Farhana. (2015). "SINR, RSRP, RSSI And RSRQ Measurements In Long Term Evolution Networks" International Journal of Wireless \& Mobile Networks (Vol.7.113123)

[2] Efriyendro, Rendi dan Yusnita Rahayu. (2017 ).“Analisa Perbandingan Kuat Sinyal

4G LTE Antara Operator Telkomsel dan XL AXIATA Berdasarkan Paramater Drive Test Menggunakan Software G-NetTrack Pro Di Area Jalan Protokol Panam". Jurnal FTEKNIK Vol.4 No. 2.

[3]Huawei Proprietary and Confidential. (2010). "LTE/SAE System Overview". Huawei Technolgies Co., Ltd. Issue 01.

[4]Yufiansa, Maria, Yusnita (2019).

"Peningkatan Performasi Jaringan 4G LTE Berdasarkan Pengecekan Sinyal di Kecamatan Bukit Sundi Kabupaten Solok" Elektron Jurnal Ilmiah (Vol 11 No 2 hal 4955 Desember 2019)

[5] Tamtama, Utami (2017). "Analisis Kinerja Coverage \& Kualitas Sinyal 4G LTE Pada Operator Seluler di Kota Purbalingga" Media Elektronika (Vol 10 No 2 Desember 2017) ISSN 2579-972x 